\title{
EFEKTIFITAS DAN EFISIENSI PENYELESAIAN SENGKETA EKONOMI SYARIAH DI PERADILAN AGAMA
}

\author{
Hasanuddin Muhammad \\ Universitas Islam Negeri Raden Intan Lampung \\ Jl. Letnan Kolonel Endro Suratmin, Sukarame, Kota Bandar Lampung \\ Email: hasanuddinmuhammad86@gmail.com
}

\begin{abstract}
The Supreme Court as the highest judicial body should realize effective and efficient justice with the principle of simple, fast and low cost. This study examines the extent to which the Supreme Court Regulations regulate and realize an effective and efficient judicial system in resolving Islamic economic disputes in religious courts. This type of research is qualitative with a normative juridical approach. As a result, the Supreme Court has issued several rules as an effort to realize an effective and efficient judiciary, namely Supreme Court Regulation Number 2 of 2015 concerning the procedure for simple lawsuit resolution, Supreme Court Regulation Number 14 of 2016 concerning Procedures for Settling Sharia Economic Disputes, Regulation of the Supreme Court Number 5 year 2016 concerning Sharia Economic Judge Certification, Supreme Court Regulation 04 of 2019 concerning Amendment to Supreme Court Regulation Number 02 of 2015 concerning Simple Settlement Procedures and Supreme Court Regulations 01 of 2019 concerning Electronic Case and Trial Administration. The Regulation regulates efforts to realize resolution Sharia economic disputes that are effective and efficient, namely through a simple lawsuit, judges must have competence in the field of sharia economics by issuing a sharia economic judge certification policy and providing judicial services electronically.
\end{abstract}

Keywords: Effectiveness, Efficiency, Islamic Economic Dispute, Religious Court

Abstrak: Mahkamah Agung sebagai badan peradilan tertinggi sudah semestinya mewujudkan peradilan efektif dan efisien dengan prinsip sederhana, cepat dan biaya ringan. Penelitian ini mengkaji sejauhmana Peraturan Mahkamah Agung itu mengatur dan mewujudkan sistem peradilan yang efektif dan efisien dalam menyelesaikan sengketa ekonomi syariah di peradilan agama. Jenis penelitian adalah kualitatif dengan pendekatan yuridis normatif,. Hasilnya, Mahkamah Agung telah mengeluarkan beberapa aturan sebagai upaya mewujudkan peradilan efektif dan efisien yaitu Peraturan Mahkamah Agung Nomor 2 Tahun 2015 tentang Tata Cara Penyelesaian Gugatan Sederhana, Peraturan Mahkamah Agung Nomor 14 Tahun 2016 tentang Tata Cara Penyelesaian Sengketa Ekonomi Syariah, Peraturan Mahkamah Agung Nomor 5 Tahun 2016 tentang Sertifikasi Hakim Ekonomi Syariah, Peraturan Mahkamah Agung Nomor 04 Tahun 2019 Tentang Perubahan Atas Peraturan Mahkamah Agung Nomor 02 Tahun 2015 Tentang Tata Cara Penyelesaian Sederhana, dan Peraturan Mahkamah Agung Nomor 01 Tahun 2019 Tentang Administrasi Perkara dan Persidangan Secara Elektronik. Perma tersebut mengatur upaya mewujudkan penyelesaian sengketa ekonomi syariah yang efektif dan efisien yaitu melalui gugatan sederhana, hakim mengadili harus miliki kompetensi di bidang ekonomi syariah dengan mengeluarkan kebijakan sertifikasi hakim ekonomi syariah, dan menyediakan pelayanan peradilan secara elektronik.

Kata kunci: Efektifitas, Efisiensi, Sengketa Ekonomi Syariah, Peradilan Agama

\section{Pendahuluan}

Sebelum adanya putusan Mahkamah Konstitusi Nomor 93/PUU-X/2012, terjadi dualisme penyelesaian sengketa ekonomi syariah, dimana menurut penjelasan pasal 55 ayat (2) Undang-Undang No. 21 Tahun 2008 Tentang Perbankan Syariah terdapat pilihan forum yaitu penyelesaian sengketa melalui peradilan umum, sedangkan pada pasal 49 Undang-Undang No. 03 Tahun 2006 Tentang Perubahan Atas Undang-Undang Nomor 7 Tentang Peradilan Agama memberikan kewenangan kepada Peradilan Agama. Dualsime tersebut membuat penyelesaian sengketa ekonomi syariah tidak 
efektif. Pasca putusan Mahkamah Konstitusi tersebut, posisi peradilan agama sebagai satusatunya badan peradilan yang berwenang untuk menyelesaikan perkara sengketa ekonomi syariah semakin kuat secara hukum. Putusan Mahkamah Konstitusi telah sejalan dengan semangat yuridis sebagaimana yang telah tertuang dalam Undang-Undang No. 03 Tahun 2006 Tentang Perubahan Atas Undang-Undang Nomor 7 Tentang Peradilan Agama. ${ }^{1}$ Menurut data pada Direktori Putusan Mahkamah Agung Republik Indonesia, ada 1159 Kasus yang telah ditangani oleh Peradilan Agama. Beberapa contoh kasus yang telah diputus yaitu Gugatan Wanprestasi Akad Ijarah yang telah diputus Pengadilan Agama Wonosari dengan Putusan Nomor: 0374/Pdt.G/2016/PA.Wno. Gugatan Sederhana Akad Pembiayaan Syariah pada pengadilan Agama Semarang yang telah diputus dengan putusan Nomor: 1/Pdt.G.S/2019/ PA.Smg. Gugatan wanprestasi akad Murabahah pada Pengadilan Agama Pandegelang dengan putusan Nomor: 1/Pdt.G.S/2020/PA.Pdlg.

Selain adanya penegasan oleh Mahkamah Konstutisi, kepercayaan terhadap peradilan agama untuk menyelesaikan sengketa ekonomi syariah juga diperkuat oleh Mahkamah Agung dengan menerbitkan Peraturan Mahkamah Agung.Mahkamah Agung sebagai peradilan tertinggi, diberi kewenangan untuk menetapkan peraturan perundang-undangan peraturan sebagaimana diatur dalam pasal 8 UndangUndang Nomor 12 tahun 2011 tentang Pembentukan Peraturan Perundang-Undangan. ${ }^{2}$

Pada tahun 2008, Mahkamah Agung menerbitkan Peraturan Mahkamah Agung Nomor 02 tahun 2008 tentang Kompilasi Hukum

\footnotetext{
1 Abdurrahman Rahim, "Analisis Hukum Terhadap Putusan Mahkamah Konstitusi No. 93/Puu-X/2012 (Studi Kewenangan Absolut Peradilan Agama)", h. 19. https:// badilag.mahkamahagung.go.id/artikel/publikasi/artikel/analisishukum-terhadap-putusan-mahkamah-konstitusi-no-93puux2012-studi-kewenangan-absolut-peradilan-agama-olehabdurrahman-rahim-shimh-139, diunduh 19 Desember 2019.

2 Undang-Undang Nomor 12 Tahun 2011 Tentang Pembentukan Peraturan Perundang-undangan
}

Ekonomi Syariah (KHES). Dalam Perma tersebut dijelaskan bahwa bagi setiap hakim pengadilan agama yang memeriksa dan mengadili perkara segketa ekonomi syariah agar menggunakan prinsip syariah sebagaimana diatur dalam KHES. Disamping itu, hakim tetap diberikan kebebasan untuk menggali dan menemukan hukum untuk menghasilkan putusan yang adil dan benar. ${ }^{3}$ KHES terdiri dari Buku I yang membahas tentang Subyek Hukum dan Amwal, Buku II membahas tentang akad, Buku III membahas tentang Zakat dan Hibah, Buku IV membahas tentang akuntansi syariah. ${ }^{4}$

Pada tahun 2016, Mahkamah Agung menerbitkan Peraturan Mahkamah Agung Nomor 14 Tahun 2016 Tentang Tata Cara Penyelesaian Sengketa Ekonomi Syariah. Perma tersebut merupakan jawaban atas ketiadaan hukum acara perdata bidang ekonomi syariah. Perma terdiri dari sebelas bab dan lima belas pasal. Dalam pertimbangannya dijelaskan bahwa perkembangan ekonomi syariah dengan berbagai bentuk transaksi keperdataannya dimasyarakat sangat signifikan. Hal tersebut membawa konsekuensi adanya potensi sengketa antar para pihak yang bertransaksi dengan prinsip-prinsip ekonomi syariah. Maka dibutuhkan payung hukum yang jelas untuk menjamin kepastian hukum bagi para pihak dalam melakukan upaya hukum terhadap pemenuhan hakhaknya. Terutama upaya-upaya hukum yang cepat, sederhana dan biaya ringan sehingga permasalahan dapat segera diselesaikan dan tidak berlarut. ${ }^{5}$

Adanya Perma yang menjadi basis hukum materiil (Perma No. 02 Tahun 2008 Tentang Kompilasi Hukum Ekonomi Syariah) dan hukum formil Perma No. 14 Tahun 2016

\footnotetext{
3 Peraturan Mahkamah Agung Nomor 02 Tahun 2008 Tentang Kompilasi Hukum Ekonomi Syariah

4 Hasneni, "Kompilasi Hukum Ekonomi Islam (Analisa Terhadap Kekuatan Hukum Dan Materinya”, Jurnal Al Hurriyah, Vol. 1, No. 2, Juli 2016, h. 189.

5 Peraturan Mahkamah Agung Nomor 14 Tahun 2016 Tentang Tata Cara Penyelesaian Sengketa Syariah.
} 
Tentang Tata Cara Penyelesaian Sengketa Ekonomi Syariah) menegaskan bahwa Mahkamah Agung berkomitmen untuk menyediakan mekanisme hukum yang pasti bagi para pencari keadilan. Sebelumnya adanya Perma. No. 14 Tahun 2016 Tentang Tata Cara Penyelesaian Sengketa Ekonomi Syariah, tidak ada kepastian hukum mengenai hukum acara yang digunaka untuk mengadili perkara ekonomi syariah. Lebih lanjutnya, terbitnya Perma No. 01 Tahun 2019 Tentang Administrasi Perkara di Pengadilan Secara Elektronik merupakan jawaban dari Mahkamah Agung untuk mewujudkan peradilan yang efektif dan efesien dengan prinsip cepat, sederhana dan biaya ringan. Di dalam Perma ini upaya mewujudkan peradilan efektif dan efisien telah diatur secara teknis bagaimana cara menerapkan asas tersebut. Berbagai instrument untuk mewujudkan asas peradilan dalam Perma ini antara lain mengakomodir penggunaan sistem elektronik yang memudahkan pihak-pihak pengguna peradilan. Tiap pihak yang telah menggunakan sistem administrasi eletronik peradilan akan dimudahkan untuk proses pemanggilan melalui elektronik karena memangkas biaya pemanggilan. Tentu semangat menghadirkan peradilan efektif dan efisien secara esensi sejalan dengan tujuan ekonomi Syariah, yaitu mewujudkan kemaslahatan bagi umat manusia. ${ }^{6}$ Karena prakitk usaha berbasis ekonomi syariah tidak hanya dikembangkan oleh umat muslim saja. ${ }^{7}$

Pada tulisan ini, penulis akan mengkaji sejauh mana ketentuan berbagai peraturan perundang-undangan untuk menjamin terwujudkan peradilan yang efektif dan efesien dengan prinsip cepat, sederhana dan biaya ringan. Mengingat di era revolusi industri 4.0 yang

${ }^{6}$ Khairuddin Wahid, "Signifikansi Lembaga Al- $\underline{\text { Hisbah }}$ Dalam Sistem Ekonomi Islam”, Jurnal Ilmiah Mizani, Vol. 5, No. 1, 2019, h.136.

Toha Andiko, "Signifikansi Implementasi Konsep Ekonomi Islam Dalam Transaksi Bisnis Di Era Modern”, Jurnal Ilmiah Mizani, Vol. 4, No. 2, 2018, h. 21. identik dengan kecepatan dan fleksibelitas kerja serta peningkatan layanan dan pendapatan. ${ }^{8}$ Penulis menggunakan pendekatan yuridis normative, dengan menganalisa ketentuan pasal yang ada di dalam Perma untuk melihat apakah ketentuan pasal-pasal tersebut secara teknis yuridis mengarah kepada asas peradilan cepat, sederhana dan biaya ringan.

\section{Kedudukan Perma dalam Hukum Indonesia}

Mahkamah Agung selain memiliki kewenangan untuk melakukan pengawasan terhadap peradilan dibawah kekuasaan Mahkamah Agung, memberikan pertimbangan hukum, ${ }^{9}$ memeriksa perkara Kasasi dan Peninjauan Kembali, menguji peraturan peraturan perundang-undangan di bawah undang-undang. Mahkamah Agung juga diberikan kewenangan untuk membuat dan menetapkan peraturan perundang-undangan. Kewenangan tersebut didasarkan pada ketentuan pasal 8 ayat (1) UU. No.12 tahun 2011 tentang Pembentukan Perundang-Undangan. Pada pasal tersebut dijelaskan bahwa jenis peraturan perundangundangan yang diakui salah satunya adalah peraturan yang ditetapkan oleh Mahkamah Agung. Pada pasal 8 ayat (2) dijelaskan bahwa kedudukan Perma diakui sebagai salah satu jenis peraturan perundang-undangan yang memiliki kekuatan hukum mengikat sepanjang diperintah oleh peraturan perundangan-undangan yang lebih tinggi. ${ }^{10}$

Kewenangan Mahkamah Agung menerbitkan Perma merupakan kewenangan yang atributif, yaitu kewenangan yang lahir karena perintah peraturan perundang-undangan.Kewenangan

${ }^{8}$ Hoedi Prasetyo and Wahyudi Sutopo, "Industri 4.0: Telaah Klasifikasi Aspek Dan Arah Perkembangan Riset,”J@ ti Undip : Jurnal Teknik Industri, Vol. 13, No. 1, Maret 2018, h. 17-26.

${ }^{9}$ Tamin, Budianto Eldist Daud. "Tinjauan Yuridis Terhadap Kedudukan Peraturan Mahkamah Agung (Perma) Dalam Hierarki Peraturan Perundang-Undangan di Indonesia," Lex Asministratum, Vol. 6, No. 3, 2018, h. 114

10 Undang-Undang Nomor 12 Tahun 2011 Tentang Pembentukan Peraturan Perundang-Undangan. 
ini lahir dari perangkat Negara dan secara resmi kewenangan ini menjadi unsur legalitas keabsahan Peraturan Mahkamah Agung. ${ }^{11}$

Mahkamah Agung sebagai salah satu pelaksana kekuasaan bidang peradilan merupakan peradilan tertinggi diberi kewenangan untuk menerbitkan Surat Edaran Mahkamah Agung dan Peraturan Mahkamah Agung. Perma merupakan peraturan perundangundangan yang dibutuhkan untuk melengkapi peraturan perundang-undangan yang sudah ada. Artinya Mahkamah Agung dibenarkan menerbitkan Perma dalam rangka memenuhi keperluan hukum tertentu karena terjadinya ketidaklengkapan aturan hukum sehingga dapat mengancam proses penegakan hukum terutama dalam pemeriksaan perkara. Untuk itu setiap Perma yang diterbitkan oleh Mahkamah Agung harus memiliki sandaran hukum.Perma merupakan peraturan perundang-undangan yang sifatnya delegatif. ${ }^{12} \mathrm{Hal}$ ini sejalan dengan ketentuan pasal 79 undang-undang nomor 14 tahun 1985 tentang mahkamah agung bahwamahkamah agung dapat membuat aturan lebih lanjut dalam mana kala terjadi kekosongan hukum demi melancarkan proses peradilan. ${ }^{13}$

Merujuk pada penjelasan sebelumnya bahwa Perma merupakan aturan pelengkap dan bersifat delegatif, maka materi hukum yang dapat diatur dalam Perma juga dibatasi pada aturan tertentu. Pertama materi yang dapat diatur dalam Perma adalah materi yang belum diatur dalam undangundang dan hanya mengatur seputar proses penyelenggaraan peradilan. Kedua materi Perma tidak boleh mencampuri dan melampaui aturan mengenai hak dan kewajiban warga Negara. ${ }^{14}$

\footnotetext{
${ }^{11}$ Nomensen Sinamo, Hukum Administrasi Negara, (Jakarta: Jala Pernata Aksara, 2014), h. 112.

${ }^{12}$ Husma, Rani, Hasyim, Kewenangan Pengaturan Mabkamah Agung, h. 5.

13 Undang-Undang Nomor 14 Tahun 1985 Tentang Mahkamah Agung.

14 Sholikin, "Mencermati Pembentukan Peraturan Mahkamah Agung (Perma)", Jurnal Recvinding, Vol. 3, No. 1, 2017, h. 2.
}

Perma dapat dijadikan sebagai terobosan hukum untuk menjawab kebutuhan dan untuk kelancaran penegakan hukum di Indonesia. ${ }^{15}$ Satu sisi kemajuan teknologi dan meningkatnya kebutuhan masyarakat acap kali menimbulkan permasalahan baru. Sisi lain hukum yang ada tidak mampu mengakomodir semua persoalan yang timbul, akibatnya terjadi kekosongan hukum. Maka hadirnya Perma adalah suatu jawaban untuk memperjelas dan menjamin kepastian hukum proses peradilan.

\section{Konsep Peradilan Efektif dan Efisien}

Konsepsi peradilan efektif dan efisiensi dalam tulisan ini mengacu kepada asas peradilan cepat sederhana dan biaya ringan sebagai diatur dalam pasal 2 undang-undang nomor 48 tahun 2009 tentang kekuasaan kehakiman. Dalam penjelasannya sederhana dimakasudkan sebagai bentuk pemeriksaan dan penyelesaian perkara dilakukan dengan cara yang efektif dan efesien. Kemudian biaya ringan adalah biaya proses peradilan dapat dijangkau oleh masyarakat. Tentu asas cepat, sederhana dan biaya ringan tidak boleh mengabaikan ketelitian dan kecermatan hakim dalam mengadili perkara. ${ }^{16}$

Untuk dapat mengetahui sejauhmana garansi terwujudnya asas cepat, sederhana dan biaya ringan dalam penyelesaian sengketa ekonomi syariah dapat dilihat dalam dua hal yaitu pertama melihat pada tataran regulasinya/ aturan hukumnya dan kedua melihat pada sisi implemntasinya. Khusus dalam tulisan ini akan membahas pada aspek regulasinya. Pada tulisan ini akan dibahas tentang ketentuanketentuan pasal yang ada pada Perma 14 Tahun 2016 tentang Tata Cara Penyelesaian Sengketa Ekonomi Syariah.

Agung Riyardi di dalam tulisannya memaknai efektivitas adalah keadaan bekerja sesuai dengan

\footnotetext{
${ }^{15}$ Sholikin, "Mencermati Pembentukan...", h. 2.

16 Undang-Undang Nomor 14 Tahun 1985 Tentang Mahkamah Agung.
} 
aturan dengan memberikan efek dan hasil. Lalu efesiensi dimaknai ketepatan cara kerja dalam mengerjakan sesuatu dengan memaksimal waktu, tenaga dan biaya tanpa ada pemborosan. ${ }^{17}$ Mengacu pada pendapat tersebut, yang perlu diperhatikan pada saat melakukan pekerjaan adalah aturannya dan ketepatan cara kerja agar menghemat waktu, tenaga dan biaya. Dalam konteks penyelesaian sengketa ekonomi syariah, tentu harus jelas bagaimana mekanismenya dan apakah mekanisme tersebut sudah mengarah kepada penjaminan upaya penyelesaian sengketa yang hemat biaya, waktu dan tenaga dengan mengacu pada asas cepat, sederhana dan biaya murah.

Berdasarkan analisa penulis dengan mengkaji Perma 14 Tahun 2016 tentang Tata Cara Penyelesaian Sengketa Ekonomi Syariah, ada beberapa ketentuan yang sejalan dengan asas peradilan cepat, sederhana dan biaya ringan untuk mewujudkan efektivitas dan efesiensi penyelesaian perkara yaitu tersedianya akses gugatan sederhana, sertifikasi hukum ekonomi syariah, tersedianya akses gugatan elektronik dan bantuan teknologi, berikut uraiannya:

\section{Tersedianya Akses Gugatan Sederhana}

Perma No. 2 tahun 2015 dan Perma No. 4 tahun 2019 perubahan Perma No. 5 tahun 2015 tentang tata cara penyelesaian gugatan sederhana menginginkan adanya penyederhanaan proses peradilan agar dapat mempermudah masyarakat untuk mengakses peradilan sederhana, cepat dan biaya ringan. Hal ini dikarenakan semakin meningkatnya hubungan hukum dalam bidang ekonomi dengan berbagai model transaksi yang mengandung potensi konflik. Penyederhanaan prosedur ini merupakan upaya nyata yang dilakukan oleh Mahkamah Agung agar menciptakan peradilan yang efektif dan efesien sehingga setiap perkara yang diperiksa

\footnotetext{
${ }^{17}$ Riyardi, "Analisis Efisiensi, Efektivitas dan Responsibilitas Kapasitas Sumber Daya Manusia Pemerintah Daerah Sragen”, Jurnal Jejak, Vol. 4, No. 2, 2011, h. 93.
}

tidak berlarut-larut dan merugikan para pihak yang berkepentingan baik itu kerugian materi maupun kerugian immateri. ${ }^{18}$

Penyelesaian gugatan sederhana merupakan langkah atau cara peradilan untuk memeriksa perkara dengan cara sederhana dan pembuktiannya pun dengan cara yang sederhana dengan ketentuan bahwa nilai materil gugatannya maksimal sebanyak Rp. 500.000.000,00 (lima ratus juta). ${ }^{19}$ Umumnya transaksi berbasis akad syariah yang nilai materinya di bawah Rp. 500.000.000.00 (lima ratus juta rupiah) terjadi pada Baitul Maal Watanwil (BMT). BMT adalah unit usaha yang berbentuk koperasi yang mendukung usaha ekonomi kecil ke bawah. Biasanya BMT akan memberikan jasa penitipan uang (menabung) dan pinjaman pihak-pihak yang membutuhkan dana dalam skala kecil. ${ }^{20}$

Pada pasal 4 dijelaskan bahwa para pihak dalam gugatan sederhana terdiri dari penggugat dan tergugat yang masing-masing tidak boleh lebih dari satu, kecuali memiliki kepentingan hukum yang sama. Terhadap tergugat yang tidak diketahui tempat tinggalnya, tidak dapat diajukan gugatan sederhana. Bagi penggugat dan tergugat dalam gugatan sederhana berdomisili di daerah hukum yang sama. Apabila penggugat berada di luar wilayah hukum/domisili tergugat, penggugat dapat menunjuk kuasa, kuasa insidentil, atau wakil yang beralamat di wilayah hukum/domisili tergugat atau dengan surat tugas dari institusi Penggugat. Penggugat dan tergugat wajib menghadiri secara langsung setiap persidangan dengan atau tanpa didampingi oleh kuasa hukum, yang artinya dalam gugatan

\footnotetext{
18 Peraturan Mahkamah Agung Nomor 14 Tahun 2016 Tentang Tata Cara Penyelesaian Sengketa Syariah.

19 Peraturan Mahkamah Agung 04 Tahun 2019 Tentang Perubahan Atas Peraturan Mahkamah Agung Nomor 02 Tahun 2015 Tentang Tata Cara Penyelesaian Sederhana.

20 Reonika Puspita Sari, "Urgensi Usul Fikih Dalam Perkembangan Lembaga Keuangan Syariah (Studi Pelaksanaan Penetapan Besaran Infak Atas Pembiayaan di BMT Nurul Husna Batanghari Lampung Timur)," Jurnal Ilmiah Mizani, Vol. 5, No. 1, Desember 2018, h. 14.
} 
sederhana tidak diperbolehkan menggunakan jasa advokat. Lamanya penyelesaian gugatan sederhana ditentukan yaitu maksimal 25 hari sejak sidang pertama. ${ }^{21}$

Selanjutnya tahapan penyelesaian gugatan sederhana sebagaimana yaitu meliputi langkah berikut:

\section{Pendaftaran}

Penggugat mendaftarkangugatannyadibagian kepaniteraan pengadilan. Penggugat dapat mendaftarkan gugatannya dengan mengisi blanko yang disedikan di kepaniteraan.Opsi mengisi blanko ini sifat pilihan, artinya penggugat dapat membuat sendiri gugatan dengan mengikuti format sesuai dengan aturan yaitu harus berisi identitas penggugat dan tergugat, penjelasan ringkas duduk perkara dan tuntutan penggugat. ${ }^{22}$

2. Pemeriksaan kelengkapan gugatan sederhana

Pada pasal 7 dijelaskan bahwa Panitera melakukan pemeriksaan syarat pendaftaran gugatan sederhana. Apabila setelah dilakukan pemeriksaan terdapat kekurangan syarat/ tidak memenuhi syarat maka gugatan dikembalikan. Semua gugatan sederhana dicatat pada buku registrasi khusus gugatan sederhana.Pada pasal 8 dijelaskan bahwa ketua pengadilan menetapkan biaya panjar perkara, dan penggugat wajib membayar panjar biaya tersebut.Apabila penggugat tidak mampu makan dapat mengajukan permohonan prodeo. ${ }^{23}$

3. Penetapan hakim dan penunjukan panitera pengganti

Pada pasal 9 dijelaskan bahwa ketua pe-

${ }^{21}$ Peraturan Mahkamah Agung 04 Tahun 2019 Tentang Perubahan Atas Peraturan Mahkamah Agung Nomor 02 Tahun 2015 Tentang Tata Cara Penyelesaian Sederhana.

${ }^{22}$ Peraturan Mahkamah Agung Republik Indonesia Nomor 2 Tahun 2015 Tentang Tata Cara Penyelesaian Gugatan Sederhana.

${ }^{23}$ Peraturan Mahkamah Agung Republik Indonesia Nomor 2 Tahun 2015 Tentang Tata Cara Penyelesaian Gugatan Sederhana. ngadilan menetapkan Hakim untuk memeriksa gugatan sederhana. Selanjutnya panitera menunjuk panitera penggantu untuk memeriksa perkara gugatan sederhana. Selanjutnya pada pasal 10 dijelaskan bahwa semua proses mulai dari tahap pendaftaran, penetapan hakim sampai penunjukan panitera pengganti dilakukan dalam waktu maksimal 2 hari. ${ }^{24}$

4. Pemeriksaan pendahuluan

Dalam proses pemeriksaan pendahuluan, Hakim memeriksa kelayalakan gugatan sederhana yang diajukan, apakah gugatan tersebut memenuhi ketentuan yaitu nilai materi yang digugat maksimal Rp. 500.000.000,00 (limaratus juta), perkara yang dimaksud bukan menjadi kewenangan pengadilan khusus atau tidak, dan bukan merupakan sengketa ha katas tanah. Selanjutnya hakim memeriksa berdasarkan ketentuan pada pasa 4 yaitu pengugat dan tergugat tidak boleh lebih dari satu kecuali memiliki kepentingan yang sama. Bahwa tergugat harus diketahui keberadaan, bahwa antara penggugat dan tergugat harus berdomisili pada daerah hukum yang sama, bahwa baik penggugat maupun tergugat hadir tanpa didampingi kuasa hukum. Apabila hasil pemeriksaan menyatakan perkara gugatan sederhana yang diajukan tidak memenuhi ketentuan yang ada pada pasal 3 dan 4 maka hakim mengeluarkan penetapan yang menyatakan bahwa gugatan tersebut bukan gugatan sederhana dan mencoret dari buku register perkara dan memerintahkan untuk mengembalikan panjar perkara. Terhadap penetapan tersebut tidak dapat dilakukan upaya hukum. ${ }^{25}$

${ }^{24}$ Peraturan Mahkamah Agung Republik Indonesia Nomor 2 Tahun 2015 Tentang Tata Cara Penyelesaian Gugatan Sederhana.

25 "Peraturan Mahkamah Agung Republik Indonesia Nomor 2 Tahun 2015 Tentang Tata Cara Penyelesaian Gugatan Sederhana." 
5. Penetapan hari sidang dan pemanggilan para pihak

Hakim menetapakan hari sidang pertama, dan pemanggilan para pihak mengacu pada ketentuan hukum acara perdata yaitu maksimal 3 hari sebelum sidang pertama. ${ }^{26}$ Apabila penggugat tidak hadir maka gugatan dinyatakan gugur. Apabila tergugat tidak hadir maka akan dilakukan pemanggilan kembali secara patut. Apabila tergugat kembali tidak hadir maka hakim memutus perkara. Apabila tergugat hadir pada sidang pertama dan sidang kedua tidak hadir maka gugatan diperiksa dan diputus secara contradictoir. Terhadap putusan tersebut dapat diajukan keberatan.Pada pasal 21 dijelaskan bahwa keberatan dilakukan paling lambat 7 hari setelah putusan dibacakan atau diberitahun kepada para pihak. Pihak yang mengajukan keberatan menyerahkan berkas permohonan keberatan dan memori keberatan ke panitera. Pihak lawan dapat mengajukan kontra memori keberatan. Hakim melakukan pemeriksaan terhadap keberatan didasarkan pada putusan dan berkas gugatan sederhana, permohonan keberatan, memori keberatan dan kontra memori keberatan.Putusan keberatan paling lambat diucapkan 7 hari setelah penetapan majelis hakim. Putusan keberatan diberitahukan kepada para pihak paling lambat 3 hari setelah putusan diucapkan. ${ }^{27}$

6. Pemeriksaan sidang dan perdamaian

Pada saat sidang pertama, hakim wajib mengupayakan perdamaian dengan tetap memperhatikan batas waktu. Apabila terjadi perdamaian maka hakim akan membuat putusan akta perdamaian, dan terhadap putusan perdamaian tidak dapat dilakukan

${ }^{26}$ M. Yahya Harahap, Hukum Acara Perdata, (Jakarta: Sinar Grafika, 2012), h. 225.

${ }_{27}$ Peraturan Mahkamah Agung Republik Indonesia Nomor 2 Tahun 2015 Tentang Tata Cara Penyelesaian Gugatan Sederhana. upaya hukum apapun. Hakim tidak terikat kesepakatan perdamaian diluar persidangan. Selanjutnya jika tidak ada perdamaian maka akan dilanjutkan pembacaan gugatan dan jawaban pihak tergugat. Proses pemeriksaan gugatan sederhana tidak dapat diajukan provisi, eksepsi, rekonvensi, intervensi, replik, duplik atau kesimpulan. ${ }^{28}$

Apabila penggugat tidak hadir pada sidang pertama, maka gugatan gugur.Dalam hal tergugat tidak hadir pada sidang pertama maka dilakukan pemanggilan ulang secara sah patut. Apabila tergugat tidak hadir dalam sidang kedua setelah dipanggil secara sah dan patut maka perkara diputus secara verstek. Apabila tergugat hadir pada sidang pertama, kemudian sidang kedua tidak hadir tanpa alasan yang sah, maka gugatan diperiksa dan diputus secara contraditoir. ${ }^{29}$

\section{Pembuktian}

Proses pembuktian pada gugatan sederhana tetap mengacu pada ketentuan hukum acara perdata yaitu bukti surat, sanksi, sangkaan, pengakuan dan sumpah. Dalil gugatan yang diakui dan tidak dibantah tidak perlu pembuktian. Penggugat wajib melampirkan bukti surat yang sudah dilegalisasi pada saat mendaftaran gugatan sederhana. ${ }^{30}$

\section{Putusan}

Hakim membacakan putusan dalam sidang terbuka untuk umum dan hakim wajib memberitahukan bahwa para pihak memiliki hak untuk mengajukan keberatan. Putusan hakim harus memuat yaitu kepala putusan, identitas para pihak, uraian singkat duduk perkara, pertimbangan hokum dana mar

\footnotetext{
${ }^{28}$ Peraturan Mahkamah Agung Republik Indonesia Nomor 2 Tahun 2015 Tentang Tata Cara Penyelesaian Gugatan Sederhana.

29 Peraturan Mahkamah Agung 04 Tahun 2019 Tentang Perubahan Atas Peraturan Mahkamah Agung Nomor 02 Tahun 2015 Tentang Tata Cara Penyelesaian Sederhana.

${ }^{30}$ Peraturan Mahkamah Agung Republik Indonesia Nomor 2 Tahun 2015 Tentang Tata Cara Penyelesaian Gugatan Sederhana.
} 
putusan. Apabila para pihak tidak bias hadir, jurusita menyampaikan pemberitahuan putusan paling lambat 2 hari setelah putusan dibacakan.Atas permintaan para pihak dapat diberikan Salinan putusan setelah 2 hari putusan dibacakan. Panitera mencatat jalannya persidangan dalam berita acara persidangan yang ditandatangani oleh hakim dan panitera pengganti.Putusan yang telah memiliki berkekuatan hukum tetap dijalankan secara sukarela, dan apabila tidak terpenuhi dapat dilakukan berdasarkan hukum acara perdata. ${ }^{31}$

Apabila para pihak tidak menjalankan putusan pengadilan secara sukarela, maka pihak berkepentingan dapat mengajukan eksekusi. Ketua pengadilan mengeluarkan penetapan aanmaning paling lambat 7 hari setelah menerima surat permohonan eksekusi. Ketua pengadilan menetapkan tanggal pelaksanaan aanmaning paling lambat 7 hari setelah penetapan aanmaning.Apabila terkendala geografis untuk melaksanaan aanmaning, maka dapat lebih dari ketentuan yang ditetapkan. ${ }^{32}$

\section{Sertifikasi Hakim Ekonomi Syariah}

Sertifikasi hakim ekonomi syariah merupakan langkah Mahkamah Agung untuk meningkatkan kesiapan peradilan agama dalam memeriksa perkara ekonomi syariah.Sertifikasi hakim ekonomi syariah bentuk simbolisasi bagi hakim-hakim yang telah memenuhi persyaratan dan telah melalui berbagai tahapan pelatihan (capacity building) sebagai hakim yang memiliki kompetensi ekonomi syariah.

Perma No. 5 tahun 2016 tentang Sertifikasi Hakim Ekonomi Syariah pasal 1 ayat (1)

${ }^{31}$ Peraturan Mahkamah Agung Republik Indonesia Nomor 2 Tahun 2015 Tentang Tata Cara Penyelesaian Gugatan Sederhana.

32 Peraturan Mahkamah Agung 04 Tahun 2019 Tentang Perubahan Atas Peraturan Mahkamah Agung Nomor 02 Tahun 2015 Tentang Tata Cara Penyelesaian Sederhana. dijelaskan bahwa sertfikasi hakim ekonomi syariah adalah proses pemberian sertifikat hakim yang telah dinyatakan lulus seleksi administrasi, kompetensi, integritas dan pelatihan menjadi hakim ekonomi syariah. Hakim ekonomi syariah merupakan hakim peradilan agama yang telah bersertifikat dan diangkat oleh ketua Mahkamah Agung.Selanjutnya dalam pasal 3 dijelaskan bahwa sertifikasi bertujuan untuk meningkatkan efektifitas penanganan perkaraperkara ekonomi syariah di pengadilan agama/ mahkamah syari'iyah sebagai bagian dari upaya penegakan hokum ekonomi syariah yang memenuhi rasa keadilan. ${ }^{33}$

Perkara ekonomi syariah sebagaimana disebutkan dalam Perma ini meliputi: bank syariah, lembaga keuangan mikro syariah, asuransi syariah, reasuransi syariah, reksadana syariah, obligasi syariah dan surat berharga berjangka menengah syariah, sekuritas syariah, pembiayaan syariah, pegadaian syariah, dana pension lembaga keuangan syariah, bisnis syariah. ${ }^{34}$

Untuk menjaminkan efektifitas penanganan ekonomis syariah, Perma ini mengatur secara tegas bahwa perkara ekonomi syariah harus diadili oleh hakim ekonomi syariah. Setiap hakim yang akan menjadi hakim ekonomi syariah harus memenuhi persyaratan administrasi, kompetensi, integritas, mengikuti pelatihan dan dinyatakan oleh tim seleksi. Persyaratan administrasi meliputi sehat jasmani dan rohani serta menjabat sebagai hakim selama 8 tahun. Persyaratan kompetensi meliputi mampu memahami norma-norma hukum ekonomi syariah, mampu menerapkan hukum sebagai instrumen dalam mengadili perkara ekonomi syariah, mampu melakukan penemuan hukum, dan mampu menerapkan pedoman beracara dalam mengadili perkara ekonomi syariah. ${ }^{35}$

\footnotetext{
${ }^{33}$ Peraturan Mahkamah Agung Republik Indonesia Nomor 5 Tahun 2016 Tentang Sertifikasi Hakim Ekonomi Syariah.

${ }^{34}$ Peraturan Mahkamah Agung Republik Indonesia Nomor 5 Tahun 2016 Tentang Sertifikasi Hakim Ekonomi Syariah.

${ }_{35}$ Peraturan Mahkamah Agung Republik Indonesia Nomor
} 
Menurut Amran Suaidi, Mahkam Agung telah bekerja sama dengan Bank Indonesia dan Otoritas Jasa Keuangan untuk meningkatkan kompetensi hakim di bidang ekonomi syariah. Pada tahun 2017, jumlah hakim yang bersertifikasi ekonomi syariah berjumlah $120{ }^{36}$ Pada tahun 2019 sekitar 208 hakim yang akan mengikuti kompetensi hakim ekonomi syariah. Persyaratan integritas adalah tidak sedang dalam menjalani hukuman. Hakim ekonomi syariah diangkat oleh ketua mahkamah agung setelah melalui tahapan seleksi dan pelatihan. Pangkatan hakim ekonomi syariah ditetapkan melalui surat keputusan ketua mahkamah agung. ${ }^{37}$

Lebih lanjut pada Perma ini juga mengatur bahwa perkara ekonomi syariah pada pengadilan tingkat pertama dan tingkat banding dilingkungan peradilan agama/mahkamah syar'iyah harus diadili oleh majelis hakim yang ketuanya dan atau salah satu anggota majelisnya merupakan hakim ekonomi syariah. Dari pasal tersebut dapat dikatakan bahwa upaya mendorong proses peradilan yang efektif dan menjamin rasa keadilan bagi masyarakat telah terencana dengan baik. Dengan skema yang diatur dalam Perma tentang Sertifikasi Hukum Ekonomi Syariah, setiap peradilan agama diarahkan untuk memiliki satu majelis hakim yang memiliki kompetensi untuk mengadili perkara ekonomi syariah.Dalam hal tidak terdapat hakim yang telah diangkat dan memiliki sertifikasi sebagai hakim ekonomi syariah, ketua pengadilan/Mahkamah Syar'iyah karena jabatannya dapat menunjuk wakil ketua atau hakim senior yang telah mengikuti diklat fungsional hakim ekonomi syariah untuk mengadili perkara ekonomi syariah. Dalam hak tidak terdapat hakim ekonomi syariah, Ketua Pengadilan/ Mahkamah Syar'iyah tingkat

\footnotetext{
5 Tahun 2016 Tentang Sertifikasi Hakim Ekonomi Syariah.

${ }^{36}$ Antara, "Baru 120 Hakim Bersertifikasi Ekonomi Syariah Sumber:, Agustus 2017, https://mediaindonesia.com/read/ detail/119201-baru-120-hakim-bersertifikasi-ekonomi-syariah.

${ }^{37}$ Peraturan Mahkamah Agung Republik Indonesia Nomor 5 Tahun 2016 Tentang Sertifikasi Hakim Ekonomi Syariah.
}

pertama/banding karena jabatanya dapat memeriksa perkara ekonomi syariah. ${ }^{38}$

\section{Tersedianya Akses Gugatan Elektronik dan Bantuan Teknologi}

Pada pasal 3 Perma No. 14 Tahun 2016 Tentang Tata Cara Penyelesaian Sengketa Ekonomi Syariah dijelaskan bahwa gugatan perkara ekonomi syariah dapat diajukan secara lisan atau tertulis dalam bentuk cetak atau pendaftaran perkara secara elektronik. Adanya ketentuan pendaftaran secara elektronik merupakan upaya Mahkamah Agung memaksimalkan penggunaan teknologi untuk mempermudah setiap pihak yang berperkara dengan lebih mengefisiensi waktu dan penggunaan kertas. Pengaturan mengenai pendaftaran elekstronik ditegaskan Perma No. 01 Tahun 2019 Tentang Administrasi Perkara di Pengadilan Secara Elektronik. Perma tersebut merupakan dasar untuk meligitimasi penyelenggaraan administrasi perkara dan persidangan secara elektronik di pengadilan untuk mewujudkan tertib penanganan perkara yang profesinal, transparan, akuntabel, efektif, efisien dan modern. ${ }^{39}$ Kemajuan teknologi di era industri 4.0 telah mendorong penggunaan system digitalisasi untuk membantu kerja manusia. Selain ramah lingkungan, penggunaan teknologi dalam administrasi berperkara akan mampu menghadirkan peradilan yang efektif dan efisien.

Administrasi perkara secara elektronik adalah serangkaian proses penerimaan gugatan/ permohonan/keberatan/bantahan/perlawanan/ intervensi, penerimaan bayaran, penyampaian panggilan/pemberitahuan, jawaban, replik, duplik, dan kesimpulan, pengelolaan, penyampaian dan penyimpanan dokumen perkara perdata/agama/tata usaha militer/tata usaha

\footnotetext{
${ }^{38}$ Peraturan Mahkamah Agung Republik Indonesia Nomor 5 Tahun 2016 Tentang Sertifikasi Hakim Ekonomi Syariah.

39 Peraturan Mahkamah Agung 01 Tahun 2019 Tentang Administrasi Perkara Dan Persidangan Secara Elektronik.
} 
negara dengan menggunakan sistem elektronik yang berlaku dimasing-masing lingkungan peradilan. Sistem peradilan elektronik yang merupakan serangkaian proses memeriksa dan mengadili perkara oleh pengadilan yang dibantu dengan teknologi informasi. Baik administrasi elektronik maupun sistem persidangan elektonik adalah dasar pembentukan sistem efekti dan efisien dalam instusi peradilan ${ }^{40}$

Pada pasal 3 dijelaskan bahwa administrasi perkara dan persidangan secara elektronik berlaku untuk jenis perkara perdata, perdata agama, tata usaha negara dan tata usaha militer. Untuk perkara banding, kasasi dan peninjauan kembali dapat dilaksanakan atas persetujuan para pihak dengan ketentuan bahwa administrasi tingkat pertama sudah dilaksanakan secara elektronik. Pada pasal 4 dijelaskan bahwa persidangan elektronik berlaku untuk proses persidangan dengan acara penyampaian gugatan/permohonan/keberatan/bantahan/ perlawanan/intervensi beserta perubahannya, jawaban, repli, duplik, pembuktian, kesimpulan dan pengucapan putusan/penetapan. ${ }^{41}$

Pada pasal 5 diatur tentang layanan administrasi perkara dan persidangan elektronik dapat digunakan oleh pengguna terdaftar dan pengguna lain. Mengenai syarat bagi advokat untuk dapat menjadi pengguna terdaftar yaitu Kartu Tanda Penduduk, Kartu Anggota Advokat, Berita Acara Sumpah Advokat oleh pengadilan tinggi. Bagi pengguna lain harus memenuhi syarat yaitu Kartu identitas pegawai/ kartu tanda anggota, surat kuasa dan/atau surat tugas dari kementerian/lembaga/badan usaha bagi pihak yang mewakili kementerian/lembaga dan badan usaha, kartu tanda penduduk/ paspor dan identitas lainnya untuk perorangan dan penetepan ketua pengadilan untuk acara secara insidentil karena hubungan keluarga

\footnotetext{
40 Peraturan Mahkamah Agung 01 Tahun 2019 Tentang Administrasi Perkara Dan Persidangan Secara Elektronik.

${ }^{41}$ Peraturan Mahkamah Agung 01 Tahun 2019 Tentang Administrasi Perkara Dan Persidangan Secara Elektronik.
}

calon pengguna terdaftar dan pengguna lain melakukan pendaftaran melalui sistem informasi pengadilan. Apabila principal mencabut kuasanya, maka harus melaporkan terlebih dahulu kepada panitera pengadilan. ${ }^{42}$

Pengguna terdaftar dan pengguna lain berhak menggunakan layanan administrasi perkara dan persidangan elektronik dengan segala fitur yang ada.Pengguna terdaftar adalah advokat yang ememnuhi syarat sebagai pengguna sistem pengadilan elektronik. Sedangkan pengguna lain adalah subjek hukum yang memenuhi syarat menggunakan sistem informasi pengadilan selain advokat yaitu jaksa pengacara negara, biro hukum/TNI/POLRI, Kejaksaaan RI, Direksi/ karyawan perusahaan dan kuasa insidentil yang ditentukan undang-undang. Pihak yang mempergunakan sistem ini terdaftar dengan menggunakan domisili elektronik. Domisili elektronik adalah domisili para pihak berupa alamat surat elektronik yang terverifikasi. Domisili elektronik adalah domisili yang dipilih pengguna terdaftar dan penggunaan lain dalam menggunakan layanan administrasi perkara dan persidangan elektronik. Setiap pengguna harus tunduk dan patuh pada peraturan yang berlaku. Mahkamah agung berwenang melakukan verifikasi data pendaftaran, verfikasi perubahan data, penangguhan terhadap akses dan pencabutan status pengguna terdaftar dan pengguna lain. Mahkamah agung berhak menolak pendaftaran pengguna terdaftar yang tidak dapat diverfikasi. Mahkamah agung dapat menindak pelanggaran yang dilakukan oleh pengguna terdaftar dan pengguna lain berupa teguran, penghentian sementara dan penghapusan akun (perberhentian selamanya). ${ }^{43}$

Pada pasal 8 dijelaskan bahwa pendaftaran perkara oleh pengguna terdaftar dan pengguna lain dapat dilakukan secara elektronik melalui

\footnotetext{
42 Peraturan Mahkamah Agung 01 Tahun 2019 Tentang Administrasi Perkara Dan Persidangan Secara Elektronik.

43 Peraturan Mahkamah Agung 01 Tahun 2019 Tentang Administrasi Perkara Dan Persidangan Secara Elektronik.
} 
sistem informasi pengadilan. Sistem informasi pengadilan ini yaitu sistem yang disediakan oleh Mahkamah Agung melalui administrasi, pelayanan perkara dan persidangan secara elektronik. Bagi penggugat, apabila akan berperkara maka harus melalui sistem informasi pengadilan dan harus disertai dengan buktibukti berupa surat dalam bentuk dokumen elektronik. Pembayaran panjar perkara sesuai dengan jumlah taksiran secara elektronik dan ditujukan ke rekening pengadilan ke bank secara elektronik. Dan jika ada penambahan biaya perkara dan pengembalian biaya dilakukan secara elektronik. Dalam hal para pihak akan melakukan upaya hukum baik banding, kasasi, dan peninajuan kembali dapat menggunakan sistem informasi pengadilan dengan ketentuan keseluruhan proses pemberkasan perkara tersebut juga dilakukan secara elektronik. ${ }^{44}$

Pada pasal 15 dijelaskan bahwa panggilan atau pemberitahuan kepada penggugat dilakukan secara elektronik dan bagi tergugat/pihak lain panggilan eletronik bisa dilakukan apabila telah disetujui. Dalam perkara tata usaha negara panggilan elektronik tidak perlu mendapat persetujuan tergugat/pihak lain. Pada pasal 16 dijelaskan bahwa hakim memerintahkan jurusita/jurusita pengganti mengirim surat panggilan ke domisili melalui panggilan elektronik. Dalam hal pihak berdomisili di luar wilayah hukum pengadilan, maka panggilan/ pemberitahuan disampaikan secara elektronik dan ditembuskan kepada pengadilan dimana para pihak berdomisili. Apabila berada di luar wilayah hukum Indonesia, panggilan/ pemberitahuan dilakukan sesuai dengan peraturan perundang-undangan. ${ }^{45}$

Hakim atau hakim ketua dapat memberikan penjelasan tentang hak dan kewajiban para pihak terkait persidangan secara elektronik pada

\footnotetext{
44 Peraturan Mahkamah Agung 01 Tahun 2019 Tentang Administrasi Perkara Dan Persidangan Secara Elektronik.

45 Peraturan Mahkamah Agung 01 Tahun 2019 Tentang Administrasi Perkara Dan Persidangan Secara Elektronik.
}

sidang pertama guna melancarkan persidangan. Persidangan secara elektronik dilaksanakan atas persetujuan para pihak setelah proses mediasi gagal. Dalam hal tidak diperlukan mediasi, maka persetujuan dilakukan pada saat sidang dihadiri oleh kedua pihak. Persetujuan penggugat diberikan pada saat pendaftaran. Jadwal sidang disampaikan oleh hakim melalui sistem informasi pengadilan. Persidangan elektronik dengan agenda penyampaian gugatan, jawaban, replik, duplik, dan kesimpulan dengan ketentuan bahwa para pihak harus menyampaikan dokumen elektronik paling lambat pada hari dan jam sidang sesuai jadwal. Setelah menerima dokumen elektronik hakim meneruskan dokumen tersebut kepada para pihak. Jawaban tergugat harus disertai dengan bukti berbentuk dokumen elektronik.Panitera wajib mencatat semua aktivitas pada persidangan elektronik dengan berita acara sidang elektronik.Apabila para pihak tidak menyampaikan dokumen elektronik sesuai dengan jadwal tanpa alasan yang sah amak dianggap tidak menggunakan haknya. ${ }^{46}$

Apabila ada pihak yang mengajukan intervensi, maka harus mengikuti prosedur persidangan elektronik, dalam tidak mentaati, maka hakim menyatakan permohonan tidak dapat diterima. Apabila kedua kedua menyepakati, pemeriksaaan saksi dapat dilakukan melalui audio visual. Persidangan elektronik menggunakan infrastruktut pengadilan, dimana setiap biaya yang timbul dalam proses persidangan ditanggung oleh penggugat. ${ }^{47}$

Putusan/penetepan diucapkan oleh hakim secara elektronik. Putusan tersebut secara hukum telah dilaksanakan dengan menyampaikan Salinan putusan/penetapan melalui sistem elektronik. Putusan/penetepan secara hukum dianggap telah dihadirioleh para pihak dan

46 Peraturan Mahkamah Agung 01 Tahun 2019 Tentang Administrasi Perkara Dan Persidangan Secara Elektronik.

47 Peraturan Mahkamah Agung 01 Tahun 2019 Tentang Administrasi Perkara Dan Persidangan Secara Elektronik. 
dilakukan dalam sidang terbuka untuk umum. Putusan/penetepan dituangkan dalam bentuk putusan/penetapan yang dibubuhi tanda tangan elektronik. Putusan/penetapan dimaksud memiliki kekuatan hukum dan dipublikasikan melalui sistem elektronik. Penegasan tentang persidangan secara elektronik melalui sistem informasi pengadilan dengan jaringan internet secara hukum telah sesuai asas dan ketentuan persidangan terbuka untuk umum.Pendaftaran dan pencatatan perkara secara elektronik yang menjadi tanggung jawab panitera pengadilan melalui sistem informasi pengadilan. Informasi perkara yang berada dalam sistem informasi pengadilan memiliki kekuatan hukum sama dengan buku register dan jurnal keuangan. ${ }^{48}$

Rangkaian proses peradilan mulai dari tahap pendaftaran perkara sampai pada tahap putusan kini telah menggunakan sistem elektronik. Dimana semua berkas yang berkaitan dengan kepentingan perkara dibuat dalam bentuk dokumen elektronik. Mulai dari dokumen gugatan, jawaban, replik, duplik, bukti-bukti dan kesimpulan. Yang paling fenomenal adalah proses persidangan berbasis pada sistem elektronik, mulai dari pemanggilan, pemeriksaan perkara, pemeriksaan saksi, sampai pada tahap putusan. Semua ketentuan tersebut sudah mengarah pada perwujudan sistem peradilan yang efisien, dengan menghemat biaya dan penggunaan kertas.

Kesiapan sarana yuridis, sarana materiil, sarana personal dan sarana finansial akan sangat berpengaruh terhadap terwujudkan peradilan efektif dan efisien. ${ }^{49}$ Pelaksanaan peraturan mahkamah agung tersebut tergantung pada kesiapan dan komitmen peradilan agama. Kesiapan yang dimaksud adalah kesiapan perangkat peradilan dalam berbagai aspek. Pertama, aspek ketersedian jaringan internet.

${ }^{48}$ Peraturan Mahkamah Agung 01 Tahun 2019 Tentang Administrasi Perkara Dan Persidangan Secara Elektronik.

${ }^{49}$ Ade Kosasih, "Penyelesaian Sengketa Kepegawaian Akibat Penjatuhan Hukuman Disiplin." Jurnal Ilmiah Mizani, Vol. 4, No. 2, Juli 2018, h. 112.
Tidak semua wilayah pengadilan mendukung ketersedian jaringan internet sehingga dapat menyulitkan berbagai pihak yang berkepentingan untuk mengakses administrasi peradilan. Kedua, kesiapan sumber daya baik hakim maupun tenaga pendukung administrasi elektronik pengadilan. Dengan jumlah 441 Pengadilan Agama dan Mahkamah Syar'iyah yang ada di Indonesia, $^{50}$ tidak menutup kemungkinan adanya kendala sumberdaya manusia. Ketiga kesiapan para pihak baik penggugat atau tergugat maupun kuasa hukum untuk mendukung proses peradilan yang efektif dan efisien. Meski hal tersebut masih perlu penelitian lebih lanjut.

\section{Penutup}

Kesimpulannya adalah bahwa berdasarkan analisa penulis Mahkamah Agung telah menerbitkan instrumen hukum yang mengatur teknis yuridis upaya mewujudkan peradilan efektif dan efisien yaitu Peraturan Mahkamah Agung Nomor 2 tahun 2015 tentang Tata Cara Penyelesaian Gugatan Sederhana, Peraturan Mahkamah Agung Nomor 14 Tahun 2016 tentang Tata Cara Penyelesaian Sengketa Ekonomi Syariah, Peraturan Mahkamah Agung Nomor 5 tahun 2016 tentang Sertifikasi Hakim Ekonomi Syariah, Peraturan Mahkamah Agung 04 Tahun 2019 Tentang Perubahan Atas Peraturan Mahkamah Agung Nomor 02 Tahun 2015 Tentang Tata Cara Penyelesaian Sederhana dan Peraturan Mahkamah Agung 01 Tahun 2019 Tentang Administrasi Perkara Dan Persidangan Secara Elektronik. Semua Perma tersebut di atas mengatur upaya mewujudkan penyelesaian sengketa ekonomi syariah yang efektif dan efisien antar lain menyediakan upaya teknis yuridis yaitu melalui jalur gugatan sederhana yang mampu menekan biaya perkara, hakim yang mengadili harus miliki kompetensi

${ }^{50}$ Hatta Ali, "Era Baru Menuju Badan Peradilan Modern", https://www.mahkamahagung.go.id/id/berita/3365/era-barumenuju-badan-peradilan-yang-modern, diunduh 5 Januari 2020. 
di bidang ekonomi syariah dengan menerbitkan kebijakan sertifikasi hakim ekonomi syariah untuk menjamin kompetensi hakim sehingga diharapkan dapat menangani perkara secara lebih efektif. Selanjutnya tersedia pelayanan adminitrasi perkara elektronik dan persidangan elektronik. Sistem ini mengharuskan tiap-tiap yang berperkara menggunakan sistem elektronik mulai dari pendaftaran gugatan sampai pada putusan sehingga dapat memperkecil biaya operasional perkara. Semua infrastruktur yang tersedia dalam rangka mewujudkan peradilan efektif dan efesien dengan prinsip cepat, sederhana dan biaya ringan akan terwujud apabila semua sumber daya manusia menjalankan ketentuan yang ada.

\section{Pustaka Acuan}

Ali, Hatta. "Era Baru Menuju Badan Peradilan Modern", https://www.mahkamahagung. go.id/id/berita/3365/era-baru-menujubadan-peradilan-yang-modern, diunduh 5 Januari 2020.

Andiko, Toha. "Signifikansi Implementasi Konsep Ekonomi Islam Dalam Transaksi Bisnis Di Era Modern.” Jurnal Ilmiah Mizani, Vol. 4, No. 1, 2018.

Antara. "Baru 120 Hakim Bersertifikasi Ekonomi Syariah Sumber:", Agustus 2017. https:// mediaindonesia.com/read/detail/119201baru-120-hakim-bersertifikasi-ekonomisyariah.

Harahap, M. Yahya. Hukum Acara Perdata, Jakarta: Sinar Grafika, 2012.

Hasneni. "Kompilasi Hukum Ekonomi Islam (Analisa Terhadap Kekuatan Hukum Dan Materinya)" 01 (July 2016).

Husma, Nelly Mulia, Faisal A Rani, and Syarifuddin Hasyim. "Kewenangan Pengaturan Mahkamah Agung” 1 (2017).

Kosasih, Ade. "Penyelesaian Sengketa Kepegawaian Akibat Penjatuhan Hukuman Disiplin.” Jurnal Ilmiah Mizani: Wacana Hukum, Ekonomi Dan Keagamaan, Vol. 4, No. 2, July 2018.
Peraturan Mahkamah Agung Republik Indonesia Nomor 2 Tahun 2015 Tentang Tata Cara Penyelesaian Gugatan Sederhana.

Peraturan Mahkamah Agung Republik Indonesia Nomor 5 Tahun 2016 Tentang Sertifikasi Hakim Ekonomi Syariah.

Peraturan Mahkamah Agung 01 Tahun 2019 Tentang Administrasi Perkara Dan Persidangan Secara Elektronik.

Peraturan Mahkamah Agung 04 Tahun 2019 Tentang Perubahan Atas Peraturan Mahkamah Agung Nomor 02 Tahun 2015 Tentang Tata Cara Penyelesaian Sederhana.

Peraturan Mahkamah Agung Nomor 14 Tahun 2016 Tentang Tata Cara Penyelesaian Sengketa Syariah.

Prasetyo, Hoedi, and Wahyudi Sutopo. "Industri 4.0: Telaah Klasifikasi Aspek Dan Arah Perkembangan Riset.”J@ti Undip: Jurnal Teknik Industri Vol. 13, No. 1, March 2018: 17. https://doi.org/10.14710/jati.13.1.17-26.

Rahim, Abdurrahman. "Analisis Hukum Terhadap Putusan Mahkamah Konstitusi No. 93/Puu-X/2012 (Studi Kewenangan Absolut Peradilan Agama)", h. 19. https://badilag. mahkamahagung.go.id/artikel/publikasi/ artikel/analisis-hukum-terhadap-putusanmahkamah-konstitusi-no-93puu-x2012studi-kewenangan-absolut-peradilanagama-oleh-abdurrahman-rahimshimh-139, diunduh 29 Desember 2019.

Riyardi, Agung. "Analisis Efisiensi, Efektivitas Dan Responsibilitas Kapasitas Sumber Daya Manusia Pemerintah Daerah Sragen" 4 (2011): 11.

Sari, Reonika Puspita. "Urgensi Usul Fikih Dalam Perkembangan Lembaga Keuangan Syariah (Studi Pelaksanaan Penetapan Besaran Infak Atas Pembiayaan Di Bmt Nurul Husna Batanghari Lampung Timur)." Jurnal Ilmiah Mizani: Wacana Hukum, Ekonomi Dan Keagamaan, Vol. 5, No. 1, Desember 2018. 
Sholikin, "Mencermati Pembentukan Peraturan Mahkamah Agung (Perma)", Jurnal Recvinding, Vol. 3, No. 1, 2017.

Sinamo, Nomensen. Hukum Administrasi Negara, Bandung: Jala Pernata Aksara, 2014.

Tamin, Budianto Eldist Daud. “Tinjauan Yuridis Terhadap Kedudukan Peraturan Mahkamah Agung (Perma) Dalam Hierarki Peraturan Perundang-Undangan di Indonesia," Lex Asministratum, Vo. 6, No. 3, 2018.
Undang-Undang Nomor 12 Tahun 2011 Tentang Pembentukan Peraturan PerundangUndangan.

Undang-Undang Nomor 14 Tahun 1985 Tentang Mahkamah Agung.

Wahid, Khairuddin. "Signifikansi Lembaga AlHisbah Dalam Sistem Ekonomi Islam." Jurnal Ilmiah Mizani, Vol. 5, No. 2, 2018. 